\title{
Lifelong Learning: The Career and Identity of Teachers in Transition
}

\author{
Rosalinda Herdeiro \\ Pedome Group of Schools, Famalicão, Portugal \\ rosalinda.herdeiro@gmail.com \\ Ana Maria Silva \\ Institute of Education, University of Minho, Portugal \\ anasilva@ie.muinho.pt
}

\section{Doi:10.5901/jesr.2013.v3n7p143}

\begin{abstract}
It is known that the professional development of the teacher includes learning opportunities that are facilitated throughout their careers and in different contexts - both formal and informal. In other words, the diversity of significant and enriching experiences that teachers encounter are favourable for the development of teachers and, consequently, of the quality of their teaching. Our proposed communication is part of a research, whose main objective to understand the impact of recent Portuguese legislation on the (re)construction of professional identity and the teaching career in the context of lifelong learning. The intended learning activities that are developed throughout life in order to acquire, develop or improve professional knowledge and skills lead the strategic plans of European governments, which are eager to achieve significant changes in the educational area. In Portugal, we question whether these political intentions have brought the desired effect(s)? To answer this question we will focus on the results from a questionnaire, which was given to 396 primary teachers and its statistical analysis, as well as on the analysis of the content of oral and written narratives and of three discussion groups formed for this purpose. The professional voices reported by the participating teachers in this study indicate results, which reveal professional discontent that has negative effects on the contexts of the educational dynamics, thus undermining up the purposes of Portuguese politics.
\end{abstract}

\section{Introduction}

Successive educational reforms, transformations brought about by the Information Society and the different needs of students are raising challenges for the school and the work of teachers, which call for ever more complex and demanding responses.

Education and training are central pillars of investment that are explicitly recognised as an urgent key requirement of the Lisbon Strategy, which induces European governments to make a political intervention that is fundamentally directed at the quality of education (Monteiro, 2008) and educational systems with different aspects to those by which they are currently constituted.

These political interventions "will challenge the professional autonomy of teachers and will raise a question about what it means to be a professional under an ever greater public scrutiny" (Day, 2001, p. 21) and which stimulate the need for teachers to be "well trained, highly motivated, with knowledge and qualifications not only at the start of their career but also throughout their professional pathway" (Day and Sachs, 2004, p. 3).

In this political and social context the capacity invested in the teacher to be capable of developing good work in school is questioned, thus triggering in the teacher a feeling of a loss of public confidence with evident repercussions in pedagogical practice.

This affective component of work, as stressed by Silva (2007, p.159), "is an important factor that interferes with the actions and emotions of professionals with impact on their performance and, above all, in their professional accomplishments."

The works of Day $(2001 ; 2004)$ confirm this interference by highlighting that the interaction of the different professional experiences of teachers within the contexts in which they work - from the classroom, to the school, to social and political contexts - results in thinking and actions of the teachers that condition, in this way, the attitudes of the teachers in the face of the need for professional development. Yet, in the opinion of the same author, in order to improve the performance of teachers their development must be defined in accordance with their personal and institutional needs 
in a way that suits their "commitment and disposition in relation to learning," while at the same time being a lifelong learner (Day, 2004, p. 186).

In this way recently driven educational changes anticipate the efficiency of teachers, as an essential requirement for the success of the students and an improvement in the quality of learning, since it is acknowledged that highly efficient teachers can have an enriching effect in the everyday life of the students, as well as in their respective educational and professional aspirations throughout their lives (Tucker and Stronge, 2007).

Moreover in the context of change European governments, particularly the Portuguese, have implemented quality education through imposed standards. This study is centred on two of them that are particularly relevant: the Statute for the Teaching Career (STC) and the Evaluation of Teaching Performance (ETP). These standards see teacher development, as the principal factor of educational change.

\section{Lifelong learning}

The concepts of training and learning throughout life have been seen to be increasingly emphasised in the political, economic, educational and social domains having been marked out in the last few decades, as a fundamental paradigm for educational and social success (Merrill et al, 2003; Merrill and Alheit, 2004; Silva, 2008; Barros, 2011; Melo, 2011).

So it is a question of omni-present concepts disseminated on a global scale in which education and training are remitted for systematic efforts, deliberated actions, rationally planned decisions and strategies specifically in formal contexts from which it is hoped that learning will take place. On the other hand, learning "focussed on a more behavioural and individual significance can be relevant not only for formal or non-formal educational actions but also in experiential situations without structured and deliberate character" (Lima, 2003, p. 131).

Historically the perspective of lifelong learning is particularly associated with documents produced by the OCDE. However, the text that is more officially accepted, as a definition for the concept of lifelong learning, was published at the end of 2000 by the European Commission. In particular the matter is treated by the Memorandum document about Lifelong Learning, which has, as its principal objective, the launching of a debate at the European level concerning a strategy for lifelong learning.

This document contains a definition of lifelong learning, which is based on the perspective that "all and any learning activity with an objective, carried out on a continuous basis," aimed at "improving knowledge, aptitudes and competencies" (European Commission, 2000, p. 3). Thus, the Memorandum perpetuates the concept, "as the guiding principle of the supply of and participation in a continuum of learning, independently of the context," thus denying it, "as being only a component of education and training" (Ibidem).

Yet, in 2001, the Commission of the European Communities - based on the impact that resulted from discussion about the Memorandum - drew up a communication entitled Making a European Area of Lifelong Learning a Reality in which it introduced a concept of great magnitude in which all of the references to lifelong learning should be understood as: "all learning activity undertaken throughout life, with the aim of improving knowledge, skills and competences within a personal, civic, social and/or employment-related perspective." (European Commission, 2001, p. 9).

This definition calls attention to a range of basic categories of learning activity and particularly to learning in formal, non-formal and informal contexts regardless of them being or not being conscious and intentional. In addition it also indicates the importance of the temporal dimension and of the multiplicity of spaces and contexts of learning. It emphasises, therefore, the continuous acquisition of knowledge and competencies for being able to take up opportunities, as well as the acquisition of new qualifications, as a way of responsibly exercising a more active and more conscious citizenship.

In this context, it is thought to be important to take up again some of the ideas implicit in the Memorandum concerning the concept under discussion and to reflect about two crucial elements that distinguish it from other conventional approaches but which give strength to the strategy outlined by European educational policies for 'Education in the 21st. Century' (Silva, 2002).

The first has to do with individual motivation for learning in all of the areas of life in a continuum of learning by valuing access to and the multiplicity of educational learning opportunities (Canário, 2007). This strategy of lifelong learning considers the whole of the process of acquiring knowledge, as an uninterrupted continuum during which it is important to provide access to learning opportunities by extending supply and demand in a way that the training is adapted to individual needs and demands and not the opposite. In this perspective, "the informal contexts offer an enormous fountain of knowledge and will constitute an important source of innovation as far as teaching and learning methods are concerned" (European Commission, 2000, p. 9). 
The second element, besides the idea of education throughout life, demands the extension of education to all sectors of life. With this intention it seeks to reinforce the importance of training contexts that are not institutionally organised by calling on decision makers for an indispensible sensibility for "valuing the multiple contexts and formative pathways in order to recognise the acquisition of experiences - in particular between adults - to extend and diversify educational opportunities on offer" (Silva, 2002, p. 146).

It is in this perspective, then, that the learning of teachers in school is centred and conceived with the intention of promoting their professional development with emerging consequences for the quality of education.

\section{Methodology and sample}

Taking as a reference the brief earlier contextualisation the authors carried out an investigation with teachers from the First Cycle of Basic Education (first four years of primary education) and some of the results are presented below. In this text the principal purpose has been to identify the participating elements in the professional development of these teachers and the implications that the afore-mentioned standards have had on their professional development.

For this purpose, the following are some of the objectives of this investigation, which more directly articulate with the results that are mentioned and discussed below: i) to identify the perspectives that the primary teachers had of the new Statute for the Teaching Career and the Evaluation of Teaching Performance; ii) to identify the motivation for teacher learning in school; iii) to find out about learning opportunities in school; and iv) to discover the learning strategies adopted by the teachers throughout their teaching career.

In this way and paying attention to the objectives identified above, the authors opted to combine both a quantative and qualitative research approach in the study.

The quantitative approach was centred on the conception, application and treatment of data from a questionnaire composed of closed questions, open questions and Likert-type scales. This questionnaire was constructed from the results of the narratives, the legislation and a review of relevant literature and it was distributed to 396 primary teachers. 249 questionnaires were returned, which corresponded to $63 \%$ of the total distributed, and these were processed and analysed later on using the SPSS (Statistical Package for the Social Sciences) programme, version 17.0.

In the sample, it should be pointed out that there were eight primary teachers that played a most important role as key informants by agreeing to be the main providers of information. They had real knowledge of experiences and were receptive to showing that they could communicate this knowledge in a spirit of steady collaboration, particularly by means of oral and written narratives at three moments during the investigation in 2007, 2008 and 2010.

This text will explain the perceptions of the primary teachers in relation to the written and oral biographical narratives collected in the three phases mentioned above and in three discussion groups formed for this purpose. Besides the perceptions pointed out in the narrative texts of the teachers, some of the results gathered from the application of the questionnaire distributed to the 396 primary teachers will be presented, as well as the statistical analyses carried out with the Chi-Square test (e.g. Table 1).

\section{Some results from the investigation}

\section{1 (De)motivation of teacher learning}

In a situation of teacher demotivation, Guerra $(2000$, p. 71$)$ argues that the teaching force "barely gets beyond the mere formal fulfilment of their administrative obligations: carrying out timetables, attending meetings, giving classes..." and it desists completely from the implementation of any innovative and maintainable practice in school.

These experiences were corroborated by the primary teachers that responded to the questionnaire, when questioned about their motivation and job satisfaction in face of the legislative policy implemented in Portugal. The teachers mentioned that it is extremely important to feel motivated in their occupation (96,0\%). Nevertheless, they recognised that the recent legislation (STC and ETP) interfered negatively with their professional motivation (62,6\%), that it impeded their professional development in school (95,5\%) and that it jeopardised the quality of their practice of teaching in a school context. 
Table 1. The demotivation of teachers with respect to professional learning

Indicators
\begin{tabular}{|l|c|c|c|}
\hline The motivation of teachers should be stimulated & Positive & Negative & \multicolumn{1}{c|}{ CTS } \\
\hline I feel motivated by current legislation & 96,0 & 4,0 & $210,6^{* * *}$ \\
\hline $\begin{array}{l}\text { It feels that the new Statute for the Teaching Career and the } \\
\text { evaluation of performance boosts my professional development }\end{array}$ & 4,4 & $\mathbf{6 2 , 6}$ & $15,6^{\star \star *}$ \\
\hline
\end{tabular}

Note: ${ }^{* \star} p<0,001$ and CST $=$ Chi-Square Test

However, we may raise some interpreting hypotheses, which result from the characteristics of our sample, such as the percentage of female teachers $(80,7 \%)$, which corresponds to the general population of primary teachers in Portugal, as well as to the age group to which most of the participating teachers of this study belong.

In this sense, a large part of the teachers, who participated in our research, are between 31 and 40 years old, which corresponds to the stabilisation/normalisation phase presented by Sikes (1985) in which the teacher considers that being competent in the work is his/her major concern, since it is a phase of greater energy, involvement and ambition. The authors warn about some specific concerns that teachers show in this phase, especially women, as they often see a possibility of progressing and developing different roles in school, due to the fact that they perform another occupation simultaneously, "the mother and wife career, which gives their [teaching] careers a secondary role" (Idem, p. 46). Besides these concerns, Sikes (Idem) refers to political, social and economic contexts, which may also condition teacher motivation to wanting or not to be more competent in his/her work. To these factors, which are more evident in women teachers, we can also add the emotional and material predisposition to invest in training, namely post-graduate training, which requires a major investment of time and money to the detriment of the family. This circumstance may be an explanatory reason for the low percentage (5.7\%) of teachers in our sample, who possess a Masters degree.

It is in this controversial scenario in which the teachers actually live out their professional experiences dependent in certain measure - on internal and external factors at school, which interferes in a negative way with their personal and professional development, thus awakening feelings and emotions that are characterised by frustration, tiredness, stress and fear.

Table 2. Factors affecting professional demotivation: internal and external to the school

\begin{tabular}{|c|c|c|}
\hline \multirow{6}{*}{ 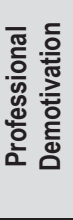 } & Factors internal to school & Factors external to school \\
\hline & Working conditions & Educational policies \\
\hline & Working environment & Bureaucratic educational system \\
\hline & Professional recognition & Social recognition \\
\hline & Relationship with peers & Permanent demand of new tasks \\
\hline & Consequences/impact on $t$ & , Tiredness, Stress, Fear \\
\hline
\end{tabular}

Analysing Table 2, it is possible to determine the indicators of demotivation that emerge, due to excessive demands (and impositions) that can be found in both spheres: internal and external to school. Of the factors external to school, the recent educational and curricular policies and unframed educational contexts are generators of other indicators - internal and external to the school - including professional demotivation with its impact on the identity of the teachers, as can be recognised in the following negatively lived and expressed experiences in the narrative voices of the following participating teachers:
"(...) creating great instability, insecurity, discontent, frustration and demotivation in the class teacher (...)" (Catarina, ON/2008).
"(...) [STC and ETP] promote disinvestment in the pedagogical activity of teachers, which inevitably will reflect itself in the quality (...)" (Gabriela, ON/2008).

In this sense, as motivation is an essential requisite for efficient professional learning and knowing that it is associated in different forms with countless factors, it will be relevant for identifying and understanding these factors and even more so, when they are hindering the stimulation of the conception of opportunities that motivate the teachers for learning and for a teaching performance of quality.

The standards for the origin of this research, (STC and EPT) have been an indelible frame for teachers and their 
work, as has been shown in the study we carried out concerning the identity lived by teachers (Dubar, 1997), which impacted on their biographical and relational experiences $(\mathrm{Idem})$ that resulted largely from the content and intentions of the previously mentioned documents and has led to a set of experiences that show fragile and often inexistent learning opportunities, which may compromise their professional realisation and development.

\subsection{Teacher learning opportunities in school}

Keeping in mind the idea that work contexts are dynamic, Guskey (1995, p. 126) proposes an "ideal combination" between professional learning and opportunities to which Day (2004) adds that the school must participate in the creation of sustained opportunities of diverse activities both inside and outside the institution in the course of a teaching career.

In this way, for example, formal group work in school or school group meetings would be an opportunity to encourage dissemination, sharing and collaboration by breaking down potential barriers to participation in all forms of reflective practice (Day, 2004; Herdeiro, 2010).

Yet the teachers feel that this space of formal learning is under used and does not encourage professional learning, as Ruivo affirmed in his discussion group: "(...) if these meetings were at the level of sharing inside the school, I think that I would be learning many more things" (Ruivo, GD3). This discontent is essentially due to the bureaucratic character imposed:

"(...) as I stressed there is little at the level of meetings, which are innumerable... almost every month there are meetings, and at times I feel that what we go there to do and what we decide in these meetings is essentially part bureaucratic (...)" (Elsa, ON/2010).

The time that is taken up in meetings means that many times the family is 'robbed' and also personal rest time lost, so they feel that their time was frankly wasted and, simultaneously, it instigates professional debilitation:

"(...) the hours that people spend in meetings (...) and which makes me so enormously tired that at times I do not have the output that I would like to have in my classroom" (Rita, GD3).

However, besides this learning opportunity, the teachers mention others present in the school, like the frequency of training actions, the co-ordination and participation in projects and pedagogical experiments in the classroom. In view of the learning opportunities provided, the teachers feel that these emerge at a different level among teachers in the same institution. In this way, they reveal that "the opportunities for development are not equal for everybody" (Q. 144). In other words, the primary teachers perceive that "(...) they do not have the same opportunities" (Q. 145) and those that exist are allocated, preferentially, to the teachers of other cycles or levels of teaching, as "(...) at the level of the school group the requests and projects are few for those who are involved" (Elsa, ON/2010).

Besides this example, the time of service that the teachers have in the school or school group seems to be seen by teachers, as the priority used by school directors, when they wish to distribute the development opportunities for the professionals of the institution. So, "(...) to start a project in a school group in which you have only been there a short time, as in my case when I had only been there one year, no chance! (...)" (Patrícia, ON/2010), because projects that already exist in school groups, "(...)are generally run by people, who already have been a long time in the school group (...)"(Ibidem) and who already belong to the circle of friends that have the power of decision: "(...) therefore, they already know them, they already know where they have to go and which people that they have to choose (...)" (Ibidem). Of course what this opportunity guarantees to the leaders/co-ordinators is a double professional satisfaction: to have been chosen by the directive body and to be seen to have their work recognised publically in face of the work of their remaining colleagues. In short "(...) only some teachers, who are directly part of the project, are recognised, the remaining teachers fade away." (Q. 242), thus influencing professional teacher identities.

The supply of training actions also does not respond to the needs of the teachers in school - both in quality and in quantity (García, 1999). The thematic imposition of training actions by the Ministry of Education is not very stimulating for teachers, as is evidenced in the following narrative:

"(...) there exists a range of training actions with little variety" (...), which do not go anyway to meet the interests of the teachers and their short-term and contextualised needs, as is the case of the excessive offering of ICT and School Library training courses (...), which at this moment, is not what worries me (...)" (Elsa, ON/2010).

In summary, teachers, although they recognise the existence of some opportunities in school, point out the many 
limitations that operate, as inhibiting factors to the construction of an attractive teaching career.

\subsection{Strategies for teacher learning and career progression}

Sikes, Measor and Woods (1985), when investigating some of the problems and continuities of teaching careers, debated some of the problems that affect careers by stressing the phenomenon of the resultant stress of the poor structure of the career and the inadequate remuneration.

In spite of the actual motivational crisis in school with its influence on commitment and performance, the teachers tried to overcome the demands and looked for new courses for professional development by giving value to a range of learning strategies (Figure 1). Of all the different professional learning strategies available, the most frequently identified by the respondent teachers focussed on Training Courses, which reflected the strategy explicitly identified in STC as being mandatory for career progression.

Figure 1. Strategies for professional learning valued by teachers

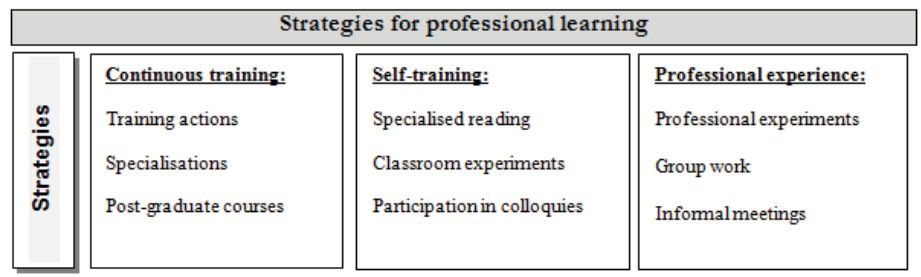

From this figure it can be inferred that the range of strategies selected by the teachers has been developed essentially in a work context, thus confirming the actual tendencies of continuous training in the way that the same would be assumed like "a real instrument of professional development of teachers" (Oliveira-Formosinho, 2009, p. 263).

In this perspective, Flores, Veiga Simão, Rajala and Tornberg (2009, p. 136) affirm that the teachers do not only attend training actions with the purpose of developing themselves socially and intellectually but also with "the objective of gaining competencies that could help them to offer their students resources and tools that will lead them to give shape to what each one wants to become".

The teachers, who are sustained by a natural will to learn how to teach better, resort to their professional experience acquired throughout their career - individually or in groups - in order to produce new knowledge, as Carlos states:

"(...)but will that not be a reflection of some learning that you yourself made during this time? Certainly, it was the benefit of some self-learning that I was doing (...)" (Carlos, GD3).

In this way, the dynamics of group reflective practice in school stands out as a means for opening up "new possibilities for action and leading to improvements in what one does" (Herdeiro, 2010, p. 106) with the help of peers and more training and professional experience in a more or less informal atmosphere. As Mário states:

"(...) I think that it will influence much more the experience that I am going to get and the life that I will have inside the school group with other colleagues, who must be responsible for helping me get better (...)" (Mário, GD1).

It is known that "the valuing of informality allows a greater direction of the formative processes for experience and for the experiential knowledge of teachers at the expense of formal external knowledge in the professional field" (Ferreira, 2009, p. 335).

Another strategy selected by the teachers is self-training. That is, autonomous learning, which is promoted and defended by Sparks and Loucks-Horsley (1990), as a development strategy, which is essentially sustainable by specialised readings, experimentation with new practices in the classroom in collaboration with peers that occurs without the existence of a formal professional development programme.

The authors declare that, when the teacher takes the initiative of learning alone by determining his/her own goals and choosing the activities that he/she thinks will result in the attainment of these objectives, it is certainly a learning 
experience (Idem).

The pursuit of specialisation and post-graduate courses in universities, which are focussed on formal contexts and in groups under the supervision of a trainer, who selects the content and the activities, is one phenomenon that has emerged with greater intensity recently, due to the agreement about continuous training being an obligatory condition for career progression (Ferreira, 2009), as expressed by Cátia: "(...) I always like to study, I have stopped now for some years, but it is only for my professional progression (...)" (Cátia, GD1). For that reason, it is natural that it will be sought by younger teachers, as a way of progressing more rapidly in their career and to reach the top to which they aspire.

In this perspective, the expressions of teachers, when considering their attendance at these courses, places them at extreme points: some attend with the intention of learning new practices and to fight against the instituted routines, as Carolina thinks: "(...) to look for a specialisation that makes me grow and develop other practices that will destroy some of my routines, I need this at this moment and not another diploma, it is not this that I want, (...)" (Carolina, ON/2010). Others attend having in mind distinct purposes, like career progression, although doubting the efficiency of their professional practice, as Mário said: "(...) I hope to get to take the Masters, which is one of the expectations that I also have, or my doctorate or whatever, but it does not seem to me that all this would directly influence what I am as a teacher (...)" (Mário, GD1).

Thus, training in context makes sense to everyone, because it corresponds to formative practices that articulate with the existential contexts of the educational actors (Ferreira, 2009). However, it is important to create working conditions in schools that permit the teacher to have time and space for his/her development jointly with colleagues whether in formal or informal contexts.

\section{Conclusion}

Nowadays, to create mechanisms and contexts that lead the teacher to a logical attitude towards professional investment all through his/her career is a necessity that schools and other external institutions must programme and direct in a way that allows the teacher to decide the projects that he/she wishes to develop and the way that they are carried out.

Therefore, it is not a question of providing solely formalised knowledge but creating conditions, contexts and opportunities for professional learning that permit the exchange of pedagogical experiences jointly with the aim of enriching teaching work.

In this way, the promotion of learning in the work place is reinforced according to Smylie (1995), as it highlights the opportunities of the individuals for working and learning with others on a continual basis and believing that learning can be improved through sharing it with others, particularly with those that possess different knowledge and experiences. Schön (1996), as well, mentions the impact of reflection - in action and on action - in teacher learning and training in an individual or collaborative context of work.

Yet in reality teachers experience obstacles throughout their career that aggravate (their) motivational crisis: For example, the moments that they are living in currently in school, as a result of the publication of the new statute and teacher evaluation, reveal that, besides other components, the central component of intrinsic reward that they obtain from their work - the response and progress of the students - is also under threat.

With the alteration of the rules related to career progression, the teachers feel themselves pressured and the priority conceded to the learning of the students is replaced by preoccupations with (their) teaching career, because they are choosing strategies of learning and development with the predominant objective of progressing in and reaching the top of the career.

However, in a context of professional teacher demotivation, Goodson (2008, p. 170) acknowledges that the changes will only develop "from a form of symbolic, political action deprived of any dedication or feeling of personal ownership or internal to the institution," if the teachers view the new reform, as sources of personal and professional inspiration

\section{References}

Barros, R. (2011). A criação do Reconhecimento de Adquiridos Experienciais (RVCC) em Portugal. Uma Etnografia Crítica em Educação de Adultos. Lisboa: Chiado Editora.

Canário, R. (2007). Multiplicar as oportunidades educativas. In Conselho Nacional de Educação (Ed.) Aprendizagem ao Longo da Vida. No Debate Nacional sobre Educação. Lisboa: CNE, 167-173.

Comissão Europeia (2000). Memorando sobre aprendizagem ao longo da vida. Bruxelas. Available at: www.eu.int/comm/education /III/life/memo.pdf (9 June 2011). 
Comissão Europeia (2001). Tornar o espaço europeu de aprendizagem ao longo da vida uma realidade. Available at: www.eu.int /comm/education/III/life/memo.pdf (9 June 2011).

Day, Ch. (2001). Desenvolvimento Profissional de Professores. Os desafios da aprendizagem permanente. Porto: Porto Editora.

Day, Ch. (2004). A Paixão pelo Ensino. Porto: Porto Editora.

Day, Ch. and Sachs, J. (2004). Professionalism, performativity and empowerment: discourses in the politics and purposes of continuing professional development. In C. Day and J. Sachs (Org.), International Handbook on the Continuing of Teachers. Maidenhead, Berks: Open University Press.

Dubar C. (1997). A Socialização. Construção das identidades sociais e profissionais. Porto: Porto Editora.

Ferreira, F. I. (2009). A formação e os seus efeitos. Do modelo escolar à formação em contexto. In J. Formosinho (Ed.), Formação de Professores. Aprendizagem profissional e acção docente. Porto: Porto Editora.

Flores, M. A., Veiga Simão, A. M.; Rajala, R. and Torneberg, A. (2009). Possibilidades e desafios da aprendizagem em contexto de trabalho: Um estudo internacional. In M. A. Flores and A. M. Veiga Simão (Ed.), Aprendizagem e desenvolvimento profissional de professores: contextos e perspectivas. Porto: Edições Pedago, 119-151.

Garcia, C. M. (1999). Formação de Professores. Para uma mudança educativa. Porto: Porto Editora.

Guerra, M. A. S. (2000). A escola que aprende. Cadernos do CRIAP. Porto: ASA Editores.

Goodson, I. F. (2008). Conhecimento e Vida Profissional. Estudos sobre educação e mudança. Porto: Porto Editora.

Guskey, Th. (1995). Professional Development in Education: In Search of the Optimal Mix. In Thomas R. Guskey and Michael Huberman (Ed.) Professional Development in Education: New Paradigms e Practices. New York: Teachers College Press, 114132.

Herdeiro, R. (2010). Trabalho Docente e Desenvolvimento Profissional. Narrativas de professores. Lisboa: Chiado Editora.

Lima, L. (2003). Formação e aprendizagem ao longo da vida: entre a mão direita e a mão esquerda de Miró. In AAVV, Cruzamento de Saberes e Aprendizagens Sustentáveis. Lisboa: Fundação Calouste Gulbenkian, 129-148.

Melo, A. (2011). Ceci n'est pas une préface. In R. Barros, A criação do Reconhecimento de Adquiridos Experienciais (RVCC) em Portugal. Uma Etnografia Crítica em Educação de Adultos. Lisboa: Chiado Editora, pp 13-20.

Merrill, B., Crossan, B., Field, J. and Gallacher, J. (2003) 'Understanding Participation in learning for Non-Traditional Adult Learners: learning careers and the construction of learning identities.' British Journal of Sociology of Education 24 (1), (0142-5692)

Merrill, B. \& Alheit, P. (2004) 'Biography and Narratives: Adult returners to learning' in Researching Widening Access to Lifelong Learning, Editors: Osborne M, Gallacher J, Crossan B. (0203300300), London: Routledge

Monteiro, A. R. (2008). Qualidade, Profissionalidade e Deontologia na Educação. Porto: Porto Editora.

Oliveira-Formosinho, J. (2009). Desenvolvimento Profissional dos professores. In J. Formosinho (Ed.) Formação de Professores. Aprendizagem profissional e acção docente. Porto: Porto Editora, 221-284.

Schön, D. (1996). A la recherche d'une nouvelle épistémologie de la pratique et de ce qu'elle implique pour l'éducation des adultes. In J.-M. Barbier (Ed.), Savoirs Théoriques et Savoirs d'Action. Paris : PUF, 201-222.

Silva, A. M. (2008). Mediação Formadora e Sujeito Aprendente ao longo da vida. In Actas do IV Colóquio Luso-Brasileiro, VIII Colóquio sobre Questões Curriculares: Currículo, Teorias, Métodos. Brasil: Universidade de Santa Catarina.

Silva, A. S. (2002). Por uma política de ideias em educação. Porto: Edições ASA.

Sikes, P; Measor, L. and Woods, P. (1985). Teacher Careers. Crises and continuities. London: The Falmer Press.

Sikes, P. (1985). The Life Cycle of the Teacher, in Stephen Ball and Ivor Goodson (Eds.) Teachers' Lives and Careers. London: The Falmer Press, 27-60.

Smylie, M. A. (1995). Teacher Learning in the Workplace: Implications for School Reform. In Thomas R. Guskey and Michael Huberman (Ed.) Professional Development in Education: New Paradigms e Practices. New York: Teachers College Press, 92-109

Sparks, D. and Loucks-Horsley, S. (1990). Models of staff development. In W. Robert Houston (Ed.) Handbook of research on teacher education. New York: Macmillan, 234-250.

Tucker, P. D. and Stronge, J. H. (2007). A avaliação dos professores e os resultados dos alunos. Porto: Edições ASA.

Ordinance no. 15/2007 of 19 January 2007

Decree no. 2/2008 of 10 January 2008 